\title{
Response of in vitro Cultured Palm Oil Seedling Under Saline Condition to Elevated Carbon Dioxide and Photosynthetic Photon Flux Density
}

\author{
Pet Roey Pascual ${ }^{1}$, Krienkai Mosaleeyanon ${ }^{2}$, Kanokwan Romyanon ${ }^{2}$ \\ and Chalermpol Kirdmanee ${ }^{2}$
}

${ }^{1}$ Cebu Technological University (CTU) - Barili Campus, Barili, Cebu, Philippines, ${ }^{2}$ National Center for Genetic Engineering and Biotechnology (BIOTEC), National Science and Technology Development Agency (NSTDA), 133 Thailand Science Park, Paholyothin Road, Klong 1, Klong Luang, Pathumthani 12120, Thailand

\begin{abstract}
Salt stress elicits various physiological and growth responses of oil palm. A laboratory experiment was conducted to determine the responses of oil palms cultured in vitro under varying salinity levels $(0,85.5,171.11,342.21$ and 684.43 $\mathrm{mM} \mathrm{NaCl})$ to elevated $\mathrm{CO}_{2}(1000 \mu \mathrm{mol} \mathrm{CO} / \mathrm{mol})$ and PPFD $\left(100 \pm 5 \mu \mathrm{mol} \mathrm{m}^{-2} \mathrm{~s}^{-1}\right)$ in terms of growth characteristics, pigment contents and photosynthetic abilities. After 14 days of culture, net photosynthetic rate $\left(\mu \mathrm{mol} \mathrm{CO}_{2} \mathrm{~m}^{-2} \mathrm{~s}^{-1}\right)$ of oil palms across varying salinity levels was 5.33 times higher than those cultured under ambient $\mathrm{CO}_{2}(380 \pm 100 \mu \mathrm{mol} \mathrm{CO} / \mathrm{mol})$ and PPFD $\left(50 \pm 5 \mu \mathrm{mol} \mathrm{m}^{-2} \mathrm{~s}^{-1}\right)$. At increased net photosynthetic rate (elevated $\mathrm{CO}_{2}$ and PPFD), despite having no significant difference in pigment contents (chlorophyll $a$, chlorophyll $b$, total chlorophyll and carotenoid) between different $\mathrm{CO}_{2}$ and PPFD levels, dry weight and percent dry matter were 0.26 and 0.11 times higher, respectively, as compared to those cultured under ambient $\mathrm{CO}_{2}$ and PPFD. In the same elevated $\mathrm{CO}_{2}$ and PPFD level, across all salinity levels, stomatal conductance was 0.30 times lower than those cultured under ambient $\mathrm{CO}_{2}$ and PPFD. At reduced stomatal conductance (elevated $\mathrm{CO}_{2}$ and PPFD), transpiration rate was also reduced by 0.30 times. Thus with increased net photosynthetic rate and reduced transpiration rate, water use efficiency was increased by 7.22 times, across all salinity levels, than those cultured at ambient $\mathrm{CO}_{2}$ and PPFD. These were considered essential for $\mathrm{NaCl}$ produces iso-osmotic stress.
\end{abstract}

Correspondence: P. R. L. Pascual. Address: Cebu Technological University (CTU) - Barili Campus, Barili, Cebu, Philippines. E-mail:petroey262301@yahoo.com.

DOI: $10.32945 /$ atr3413.2012 


\section{INTRODUCTION}

It is projected that the demand for oil will increase as a result of future increase in the world per capita consumption of oils and fats (Oil World, 2004). Palm oil can contribute significantly to meet this demand in view of its high yield (4-5t/ha/year) (Barison and Ma, 2000); almost three times the yield of coconut and more than ten times that of soybean (Rajanaidu and Jalani, 1994). Expansion of oil palm plantations will mean encroachment of forested lands which has an adverse effect on the environment. Hence, areas other than forested land such as saline areas should be considered for oil palm production. However, since oil palms are known to be susceptible to salinity, breeding for salt tolerance in oil palm is needed to be able to fully utilize the vast saline areas for expansion of oil palm plantations.

Salinity is one of the major factors affecting agricultural productivity worldwide. In Asia alone, with an estimated area of 21.5 million hectares, 12 million hectares of which are considered saline. Salt negatively affects plants by inhibiting water absorption due to increased osmotic pressure around the roots and death of cells or tissues due to abundance of $\mathrm{Na}^{+}$ (Munns and Tester, 2008). Moreover, physiological parameters have been developed as effective indices for tolerance screening in plant breeding programs (Parida and Das, 2005; Ashraf and Foolad, 2007). Jalani et al. (1997) considered tolerance of oil palm to salinity along with other abiotic stresses such as water-deficit, extreme temperature, mineral deficiency, heavy metal toxicity and ultraviolet irradiation as a fruitful topic in its improvement.

Thus, this study aimed to determine the responses of oil palm seedlings cultured in vitro under varying salinity levels to increased $\mathrm{CO}_{2}$ and PPFD level in terms of growth characteristics, pigment contents and photosynthetic abilities. These issues were considered as a profitable venture for the purpose of salt tolerance screening using physiological parameters as quicker and simpler index in oil palm breeding programs such as high net photosynthesis in plant translating to better performance under saline condition. 


\section{MATERIALS AND METHODS}

\section{Plant materials and culture condition}

Two-month-old oil palm plantlets of the variety Tenera derived from zygotic embryos of approximately $5 \mathrm{~cm}$ height with 1 to 2 opened leaves cultured in $1 / 2$ strength Murashige and Skoog (MS) medium supplemented with $3 \%$ sucrose and $0.25 \%$ Phytagel $^{\circledast}$ (Pronadisa, Hispanlab, S.A. Madrid) were selected and grown with roots removed in glass vessel under photoautotrophic condition supplemented with $50 \mathrm{ml} 1 / 2$ strength MS liquid medium (without agar and sugar) supported by vermiculite (Fig. $1 \mathrm{a}$ and $\mathrm{b}$ )

The $\mathrm{pH}$ of the media was adjusted to 5.7 to 5.8 before autoclaving. Except for the differences in treatments $\left(\mathrm{CO}_{2}\right.$ concentration and PPFD), oil palm seedlings cultured in vitro in plant growth chamber (Eyela) were subjected to the same $28 \pm 2^{\circ} \mathrm{C} / 25 \pm 2^{\circ} \mathrm{C}$ temperature shift(light/dark), $60 \pm 5 \%$ relative humidity (RH) and $16 \mathrm{~h} \mathrm{~d}^{-1}$ photoperiod as provided by $40 \mathrm{~W}$ white fluorescent tube (Fig. $1 \mathrm{c}$ ). Air exchanges between the chamber environment and the glass vessels were facilitated with two air perforations on its cover and placed with gas-permeable microporous polyethylene film $(0.22 \mu \mathrm{m}$ pore size $)$ over the holes.

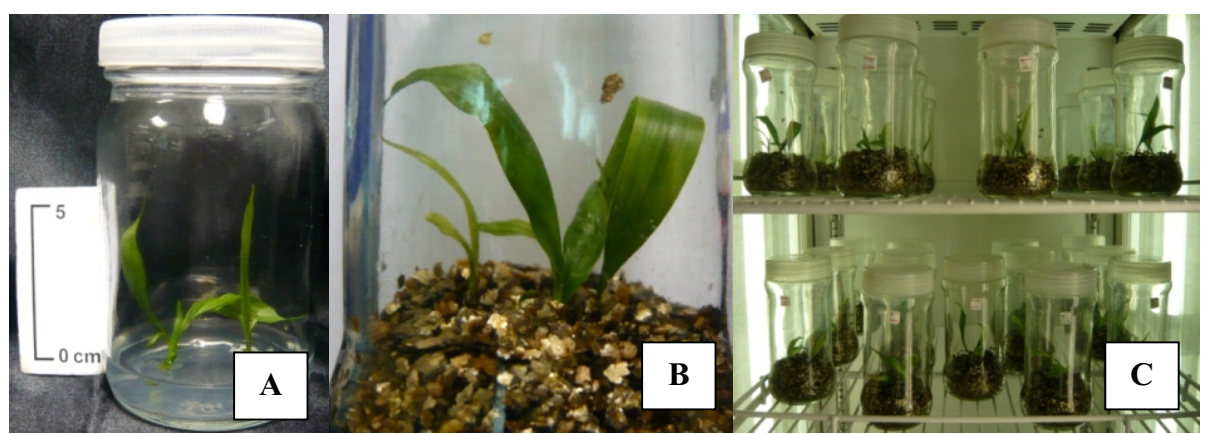

Figure 1. Two-months-old tenera plantlets derived from zygotic embryos cultured in $1 / 2$ strength MS medium (A) sub-cultured with the roots removed in glass vessel under photoautotrophic condition supported by vermiculite (B) and placed under plant growth chamber (C). 
Experimental design and treatments

A $2 \times 5$ factorial experiment arranged in Completely Randomized Design (CRD) with five replications at three plantlets per replication was used in this study. Different carbon dioxide $(380 \pm 100$ and $1000 \pm 100 \mu \mathrm{mol}$ $\mathrm{CO}_{2} / \mathrm{mol}$ ) concentrations along with light intensities $(50 \pm 5$ and $100 \pm 5$ $\left.\mu \mathrm{mol} \mathrm{m} \mathrm{s}^{-2}\right)$, and with varying levels of salinity $(0,85.5,171.11,342.21$ and $684.43 \mathrm{mM} \mathrm{NaCl}$ ) were tested (Table 1). The zygotic embryo-derived plantlets of oil palm were exposed to the different treatment conditions for a period of two (2) weeks before data were gathered. The following were the treatments of the study

Factor $\mathrm{A}-\mathrm{CO}_{2}$ and PPFD Level

A - Ambient $\mathrm{CO}_{2}$ and PPFD Level $\left(380 \pm 100 \mu \mathrm{mol} \mathrm{CO}{ }_{2} / \mathrm{mol}\right.$ and $50 \pm 5$ $\mu \mathrm{mol} \mathrm{m} \mathrm{s}^{-2}$ )

E - Elevated $\mathrm{CO}_{2}$ and PPFD Level $(1000 \pm 100 \mu \mathrm{mol} \mathrm{CO} / \mathrm{mol}$ and $100 \pm 5 \mu \mathrm{mol} \mathrm{m}^{-2} \mathrm{~s}^{-1}$ )

Factor B - Salinity Level

$\mathrm{T} 1-0.00 \mathrm{mM} \mathrm{NaCl}$

$\mathrm{T} 2-85.50 \mathrm{mM} \mathrm{NaCl}$

T3 - $171.11 \mathrm{mM} \mathrm{NaCl}$

$\mathrm{T} 4-342.21 \mathrm{mM} \mathrm{NaCl}$

T5 - $684.43 \mathrm{mM} \mathrm{NaCl}$

\section{Datagathered}

\section{Physiological responses}

Chlorophyll a (Chla), chlorophyll b (Chlb), total chlorophyll (TC) and carotenoid $\left(\mathrm{C}_{\mathrm{x}+\mathrm{C}}\right)$ were measured following the methods of Shabala et al. (1998) and Lichtenthaler (1987), respectively. One hundred milligram of leaf tissue were collected and placed into $25 \mathrm{ml}$ glass vial, added with $10 \mathrm{ml}$ of $95.5 \%$ acetone and blended with homogenizer. The Chla, Chlb, and $\mathrm{C}_{\mathrm{x}+\mathrm{C}}$ were measured with UV - visible spectrometer. Solution of $95.5 \%$ acetone was used as blank. 
The net photosynthetic rate $(\mathrm{Pn})$, transpiration rate (E) and stomatal conductance (gs) of oil palm plantlets were measured using an Infra-Red Gas Analyser (IRGA). The E and gs were measured by continuously monitoring the $\mathrm{H}_{2} \mathrm{O}$ of the air entering and exiting in the IRGA headspace chamber. Water use efficiency (WUE) of plantlets was calculated by ratio of $\mathrm{P}_{\mathrm{n}}$ and $\mathrm{E}$ (Cha-um et al.,2007).

\section{Growth characteristics}

Shoot fresh and dry weights of oil palm seedlings were measured at the end of the experiment. For dry weight, oil palm seedlings were dried at $80^{\circ} \mathrm{C}$ in a hot-air oven for 2 days, and were incubated in desiccators for 1 day before the measurement of dry weight. Dry matter data are essential as dry matter production generally increases as the plant grows and develops making it a very reliable index of plant development compared to other parameters which are greatly dependent on moisture content. Percent dry matter was calculated by ratio of dry weight and fresh weight multiplied by 100. This is also important since weight of plantlets varies even before treatment application. On the other hand, root parameters were not gathered anymore because the study focused only on determining the potential of using Pn as index for salinity tolerance.

\section{Data Analysis}

Data were statistically analyzed through ANOVA for CRD. Comparisons among means were done using DMRT to determine the specific significant differences among treatment means.

\section{RESULTS}

The combined effect of $\mathrm{CO}_{2}$, PPFD and salinity levels on net photosynthetic rate $\left(\mu \mathrm{mol} \mathrm{CO}_{2} \mathrm{~m}^{-2} \mathrm{~s}^{-1}\right)$ is shown in Table 1. Oil Palms cultured under elevated $\mathrm{CO}_{2}\left(1000 \pm 100 \mu \mathrm{mol} \mathrm{CO}_{2} / \mathrm{mol}\right)$ and PPFD $(100 \pm 5$ $\mu \mathrm{mol} \mathrm{m} \mathrm{m}^{-2}$ ) and exposed to a salinity level of $85.50 \mathrm{mM} \mathrm{NaCl}$ (T1E) exhibited the highest net phosynthetic rate, but was not significantly different to those exposed to the same elevated $\mathrm{CO}_{2}$ and PPFD level that were untreated with $\mathrm{NaCl}$ (T0E). Net phosynthetic rate in T1E was seven times higher than those seedlings cultured under ambient $\mathrm{CO}_{2}(380 \pm 100$ 
$\mu \mathrm{mol} \mathrm{CO} / \mathrm{mol})$ and PPFD ( $\left.50 \pm 5 \mu \mathrm{mol} \mathrm{m}^{-2} \mathrm{~s}^{-1}\right)$ level without $\mathrm{NaCl}(\mathrm{T} 0 \mathrm{~A})$. At salinity level above $85.50 \mathrm{mM} \mathrm{NaCl}$, however, Pn of oil palm exposed to elevated $\mathrm{CO}_{2}$ and PPFD level was not anymore statistically different to those grown under ambient $\mathrm{CO}_{2}$ and PPFD level and exposed to saline condition up to $342.21 \mathrm{mM} \mathrm{NaCl}$. Several authors have reported that an increase in PPFD enhanced net photosynthetic rate of in vitro plantlets in plant species such as Eucalyptus (Kirdmanee et al., 1995), melon (Cucumis melo L.) (Adelberge et al., 1999) and coffee (Coffea arabusta) (Nguyen et al., 2000). However, none has been reported on plants exposed to saline condition.

Table 1. Net photosynthetic rate of oil palms after 14 days of culture under controlled environments as affected by different $\mathrm{CO}_{2}$, PPFD and salinity levels. Different letters indicate significant differences between the treatments at $\mathrm{P} \leq 0.05$ determined by Duncan's Multiple Range

\begin{tabular}{ccccccc}
\hline $\mathrm{CO}_{2}$ and & \multicolumn{5}{c}{ Salinity Level (mM NaCl) } & \multirow{2}{*}{ Mean } \\
\cline { 2 - 6 } PPFD Levels & \multicolumn{1}{c}{$\mathrm{T} 0$} & $\mathrm{~T} 1$ & $\mathrm{~T} 2$ & $\mathrm{~T} 3$ & $\mathrm{~T} 4$ & \\
\hline $\mathrm{A}$ & $0.00027^{\mathrm{cd}}$ & $0.00084^{\mathrm{cd}}$ & $-0.00386^{\mathrm{cd}}$ & $-0.00440^{\mathrm{cd}}$ & $-0.00998^{\mathrm{d}}$ & $-0.00343 \mathrm{~b}$ \\
$\mathrm{E}$ & $0.02191^{\mathrm{ab}}$ & $0.02699^{\mathrm{a}}$ & $0.00927^{\mathrm{bc}}$ & $0.00811^{\mathrm{bc}}$ & $0.00005^{\mathrm{cd}}$ & $-0.00343 \mathrm{~b}$ \\
Mean & $0.01109^{\mathrm{a}}$ & $0.01391^{\mathrm{a}}$ & $0.00270^{\mathrm{ab}}$ & $0.00185^{\mathrm{ab}}$ & $-0.00049^{\mathrm{b}}$ & \\
\hline
\end{tabular}

The increase in net photosynthetic rate, despite having no significant difference in pigment contents (chlorophyll $a$, chlorophyll $b$, total chlorophyll and carotenoid in $\mu \mathrm{g} \mathrm{g}^{-1} \mathrm{FW}$ ) between ambient and elevated carbon dioxide and PPFD level (Table 2), mean dry weight (mg/plant) and percent dry matter were increased by 0.26 and 0.11 times at elevated $\mathrm{CO}_{2}$ $(1000 \pm 100 \mu \mathrm{mol} \mathrm{CO} / \mathrm{mol})$ and PPFD $\left(100 \pm 5 \mu \mathrm{mol} \mathrm{m} \mathrm{m}^{-2} \mathrm{~s}^{-1}\right)$, respectively (Table 3). Plantlets grown under elevated $\mathrm{CO}_{2}(1000 \pm 100 \mu \mathrm{mol} \mathrm{CO} / \mathrm{mol})$ and PPFD $\left(100 \pm 5 \mu \mathrm{mol} \mathrm{m}^{-2} \mathrm{~s}^{-1}\right)$ levels that were untreated with $\mathrm{NaCl}$ (T0E) had the heaviest dry weight and percent dry matter which was 0.76 and 0.37 times higher, respectively, than those oil palms gown under ambient condition that were untreated with $\mathrm{NaCl}$ (T0A). Generally, photosynthetic photon flux (PPF) and $\mathrm{CO}_{2}$ concentration are key environmental factors determining plant growth. In St. Johns wort, increasing PPF from 100 to $300 \mu \mathrm{mol} \mathrm{m} \mathrm{m}^{-2} \mathrm{~s}^{-1}$ and increasing $\mathrm{CO}_{2}$ concentration from 500 to $1500 \mu \mathrm{mol} \mathrm{mol}^{-1}$ significantly increased net photosynthetic rate that resulted to increase in fresh and dry mass (Mosaleeyanon et al., 2005). However, there were no reports on plants subjected to salinity stress. 
Table 2. Pigment contents (chlorophyll a, chlorophyll b, total chlorophyll content and carotenoid) of oil palms after 14 days of culture under controlled environments as affected by different $\mathrm{CO}_{2}$, PPFD and salinity levels. Different letters indicate significant differences between the treatments at $\mathrm{P} \leq 0.05$ determined by Duncan's Multiple Range Test.

\begin{tabular}{|c|c|c|c|c|}
\hline Treatment & $\begin{array}{l}\text { Chla } \\
\left(\mu \mathrm{g} \mathrm{g}^{-1} \mathrm{FW}\right)\end{array}$ & $\begin{array}{l}\text { Chlb } \\
\left(\mu \mathrm{g} \mathrm{g}^{-1} \mathrm{FW}\right)\end{array}$ & $\begin{array}{l}\text { TC } \\
\left(\mu \mathrm{g} \mathrm{g}^{-1} \mathrm{FW}\right)\end{array}$ & $\begin{array}{l}\mathrm{C}_{\mathrm{x}+\mathrm{c}} \\
\left(\mu \mathrm{g} \mathrm{g}^{-1} \mathrm{FW}\right)\end{array}$ \\
\hline \multicolumn{5}{|l|}{ Ambient $\mathrm{CO}_{2}$ and PPFD } \\
\hline $0.00 \mathrm{mM} \mathrm{NaCl}$ & $11.85^{\mathrm{ab}}$ & $4.71^{\mathrm{ab}}$ & $16.56^{\mathrm{ab}}$ & $3.71^{\mathrm{ab}}$ \\
\hline $85.50 \mathrm{mM} \mathrm{NaCl}$ & $13.67^{\mathrm{a}}$ & $5.52^{\mathrm{a}}$ & $19.20^{\mathrm{a}}$ & $4.43^{\mathrm{a}}$ \\
\hline $171.11 \mathrm{mM} \mathrm{NaCl}$ & $10.76^{\mathrm{ab}}$ & $4.57^{\mathrm{ab}}$ & $15.34^{\mathrm{ab}}$ & $3.36^{\mathrm{ab}}$ \\
\hline $342.21 \mathrm{mM} \mathrm{NaCl}$ & $8.34^{\mathrm{bc}}$ & $3.60^{\text {bcd }}$ & $11.94^{\mathrm{bc}}$ & $2.85^{\mathrm{bc}}$ \\
\hline $684.43 \mathrm{mM} \mathrm{NaCl}$ & $5.35^{\mathrm{cd}}$ & $2.59^{\mathrm{cd}}$ & $7.95^{\mathrm{cd}}$ & $1.81^{\mathrm{cd}}$ \\
\hline Mean & 9.99 & 4.19 & 14.19 & 3.23 \\
\hline \multicolumn{5}{|l|}{ Elevated $\mathrm{CO}_{2}$ and PPFD } \\
\hline $0.00 \mathrm{mM} \mathrm{NaCl}$ & $10.95^{\mathrm{ab}}$ & $4.27^{\mathrm{abc}}$ & $15.22^{\mathrm{ab}}$ & $3.85^{\mathrm{ab}}$ \\
\hline $85.50 \mathrm{mM} \mathrm{NaCl}$ & $10.43^{\mathrm{ab}}$ & $4.29^{\mathrm{abc}}$ & $14.72^{\mathrm{ab}}$ & $3.67^{\mathrm{ab}}$ \\
\hline $171.11 \mathrm{mM} \mathrm{NaCl}$ & $10.43^{\mathrm{ab}}$ & $4.39^{\mathrm{ab}}$ & $14.82^{\mathrm{ab}}$ & $3.92^{\mathrm{ab}}$ \\
\hline $342.21 \mathrm{mM} \mathrm{NaCl}$ & $7.85^{\mathrm{bc}}$ & $3.53^{\text {bcd }}$ & $11.39^{\mathrm{abc}}$ & $2.97^{\mathrm{abc}}$ \\
\hline $684.43 \mathrm{mM} \mathrm{NaCl}$ & $3.79^{\mathrm{d}}$ & $2.03^{\mathrm{d}}$ & $5.82^{\mathrm{d}}$ & $1.35^{\mathrm{d}}$ \\
\hline Mean & 8.69 & 3.70 & 12.39 & 3.15 \\
\hline
\end{tabular}

Table 3. Growth characteristics (fresh weight, dry weight and percent dry matter) of oil palms after 14 days of culture under controlled environments as affected by different $\mathrm{CO}_{2}$, PPFD and salinity levels. Different letters indicate significant differences between the treatments at $\mathrm{P} \leq 0.05$ determined by Duncan's Multiple Range Test

\begin{tabular}{clll}
\hline Treatment & $\begin{array}{l}\text { FW } \\
(\mathrm{mg} / \text { plant })\end{array}$ & $\begin{array}{l}\text { DW } \\
(\mathrm{mg} / \mathrm{plant})\end{array}$ & $\begin{array}{l}\% \text { DM } \\
(\% / \text { plant })\end{array}$ \\
\hline Ambient $\mathrm{CO}_{2}$ and PPFD & $117.64^{\mathrm{abc}}$ & $16.53^{\mathrm{bc}}$ & $13.98^{\mathrm{c}}$ \\
$0.00 \mathrm{mM} \mathrm{NaCl}$ & $124.20^{\mathrm{abc}}$ & $21.34^{\mathrm{abc}}$ & $16.75^{\mathrm{abc}}$ \\
$85.50 \mathrm{mM} \mathrm{NaCl}$ & $111.35^{\mathrm{bc}}$ & $16.13^{\mathrm{bc}}$ & $16.12^{\mathrm{abc}}$ \\
$171.11 \mathrm{mM} \mathrm{NaCl}$ & $104.38^{\mathrm{c}}$ & $15.22^{\mathrm{bc}}$ & $15.27^{\mathrm{bc}}$ \\
$342.21 \mathrm{mM} \mathrm{NaCl}$ & $91.66^{\mathrm{c}}$ & $13.53^{\mathrm{c}}$ & $14.48^{\mathrm{bc}}$ \\
$684.43 \mathrm{mM} \mathrm{NaCl}$ & 109.85 & $16.55^{\mathrm{b}}$ & $15.32^{\mathrm{b}}$ \\
$\mathrm{Mean}$ & & & \\
Elevated $\mathrm{CO}_{2}$ and PPFD & $149.09^{\mathrm{a}}$ & $29.15^{\mathrm{a}}$ & $19.27^{\mathrm{a}}$ \\
$0.00 \mathrm{mM} \mathrm{NaCl}$ & $146.75^{\mathrm{ab}}$ & $25.57^{\mathrm{ab}}$ & $16.83^{\mathrm{abc}}$ \\
$85.50 \mathrm{mM} \mathrm{NaCl}$ & $112.51^{\mathrm{abc}}$ & $20.37^{\mathrm{abc}}$ & $17.97^{\mathrm{ab}}$ \\
$171.11 \mathrm{mM} \mathrm{NaCl}$ & $110.30^{\mathrm{bc}}$ & $18.36^{\mathrm{bc}}$ & $16.35^{\mathrm{abc}}$ \\
$342.21 \mathrm{mM} \mathrm{NaCl}$ & $97.01^{\mathrm{d}}$ & $14.78^{\mathrm{c}}$ & $14.83^{\mathrm{bc}}$ \\
$684.43 \mathrm{mM} \mathrm{NaCl}$ & 123.13 & $21.65^{\mathrm{a}}$ & $17.05^{\mathrm{a}}$ \\
$\mathrm{Mean}$ & & & \\
\hline
\end{tabular}

In the same elevated $\mathrm{CO}_{2}$ and PPFD level, across all salinity levels, stomatal conductance $\left(\mu \mathrm{mol} \mathrm{m} \mathrm{s}^{-2} 1\right)$ of oil palm seedlings was 0.30 lower than those cultured under ambient carbon dioxide and PPFD (Fig. 2). Since 
salinity induces iso-osmotic stress, a very common mechanism for plant to cope with further loss of water is through closing of stomata. With reduced stomatal conductance (elevated carbon dioxide and PPFD), transpiration rate $\left(\mathrm{mmol} \mathrm{H}_{2} \mathrm{O} \mathrm{m}^{-2} \mathrm{~s}^{-1}\right)$ was also reduced by 0.30 times (Table 4).

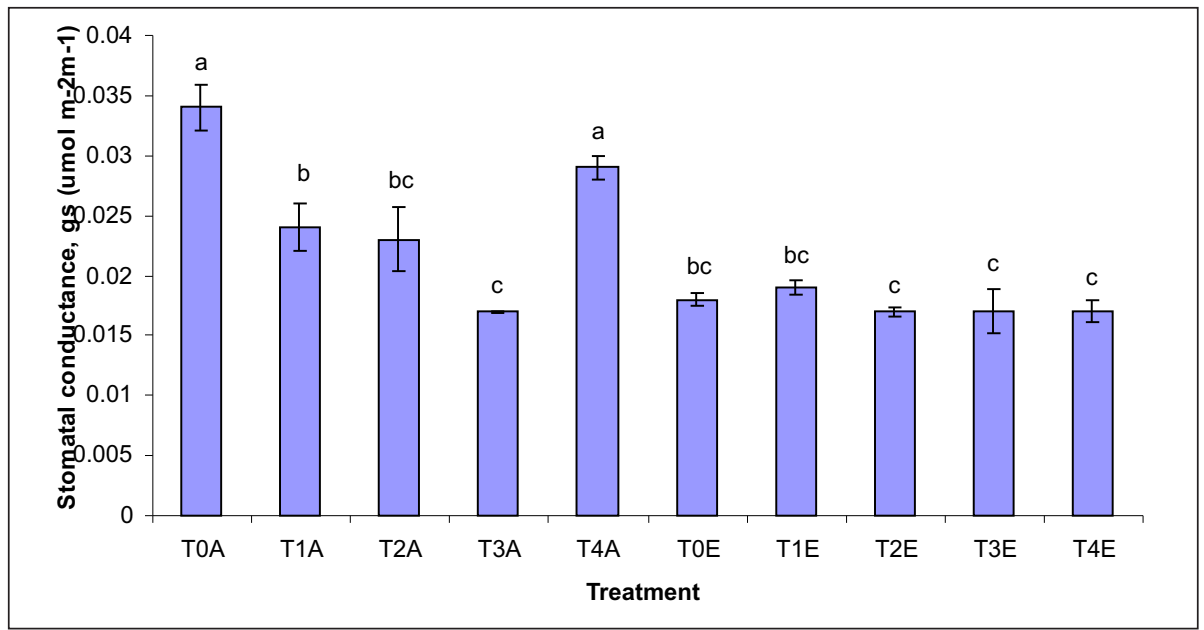

Figure 2. Stomatal conductance of oil palms after 14 days of culture under controlled environments as affected by different $\mathrm{CO}_{2}$, PPFD and salinity levels. Different letters indicate significant differences between the treatments at $\mathrm{P} \leq 0.05$ determined by Duncan's Multiple Range Test

Table 4. Transpiration rate of oil palms after 14 days of culture under controlled environments as affected by different $\mathrm{CO}_{2}$, PPFD and salinity levels. Different letters indicate significant differences between the treatments at $\mathrm{P} \leq 0.05$ determined by Duncan's Multiple Range Test

\begin{tabular}{cll}
\hline Treatment & $\begin{array}{l}\mathrm{E} \\
\left(\mathrm{mmol} \mathrm{H}_{2} \mathrm{O} \mathrm{m}^{-2} \mathrm{~s}^{-1}\right)\end{array}$ & $\begin{array}{l}\text { WUE } \\
(\mathrm{Pn} / \mathrm{E})\end{array}$ \\
\hline Ambient $\mathrm{CO}_{2}$ and PPFD & & \\
$0.00 \mathrm{mM} \mathrm{NaCl}$ & $0.88537^{\mathrm{a}}$ & $0.00030^{\mathrm{b}}$ \\
$85.50 \mathrm{mM} \mathrm{NaCl}$ & $0.62821^{\mathrm{b}}$ & $0.00133^{\mathrm{b}}$ \\
$171.11 \mathrm{mM} \mathrm{NaCl}$ & $0.60743^{\mathrm{bc}}$ & $-0.00635^{\mathrm{b}}$ \\
$342.21 \mathrm{mM} \mathrm{NaCl}$ & $0.46688^{\mathrm{cd}}$ & $-0.00942^{\mathrm{b}}$ \\
$684.43 \mathrm{mM} \mathrm{NaCl}$ & $0.76448^{\mathrm{a}}$ & $-0.01305^{\mathrm{b}}$ \\
$\mathrm{Mean}$ & $0.67047^{\mathrm{b}}$ & $-0.00544^{\mathrm{b}}$ \\
Elevated $\mathrm{CO}_{2}$ and PPFD & & \\
$0.00 \mathrm{mM} \mathrm{NaCl}$ & $0.48423^{\mathrm{cd}}$ & $0.04524^{\mathrm{a}}$ \\
$85.50 \mathrm{mM} \mathrm{NaCl}$ & $0.48735^{\mathrm{cd}}$ & $0.05538^{\mathrm{a}}$ \\
$171.11 \mathrm{mM} \mathrm{NaCl}$ & $0.44871^{\mathrm{d}}$ & $0.02065^{\mathrm{ab}}$ \\
$342.21 \mathrm{mM} \mathrm{NaCl}$ & $0.46000^{\mathrm{d}}$ & $0.01763^{\mathrm{ab}}$ \\
$684.43 \mathrm{mM} \mathrm{NaCl}$ & $0.45623^{\mathrm{d}}$ & $0.00011^{\mathrm{b}}$ \\
$\mathrm{Mean}$ & $0.46730^{\mathrm{a}}$ & $0.02780^{\mathrm{a}}$ \\
\hline
\end{tabular}


Stomatal conductance (T0A) and transpiration rate (T4A) peaks were significantly higher compared to the rest of the treatments. Thus with increased net photosynthetic rate and reduced transpiration rate, water use efficiency (Pn/E) was 7.22 times higher than those cultured at ambient carbon dioxide and PPFD, across all salinity levels.

Moreover, it is interesting to point out effect of elevated $\mathrm{CO}_{2}$ and PPFD on stomatal conductance and transpiration rate as iso-osmotic stress derived from $\mathrm{NaCl}$ induced toxic damages especially in pigment degradation (de Herralde et al., 1998; Lutts et al., 2004; Neto et al., 2004; Tonon et al., 2004). In such case, minimal loss of water due to transpiration through the stomata is very important. With the increased net photosynthetic rate and reduced transpiration rate, water use efficiency (Pn/E) of seedlings was increased by 7.22 times higher than seedlings cultured at ambient carbon dioxide and PPFD. Moreover, the up-surge of stomatal conductance transpiration at $684.43 \mathrm{mM} \mathrm{NaCl}$ at ambient carbon dioxide and PPFD may have been attributed to epidermal cell death causing stomata to lock-open.

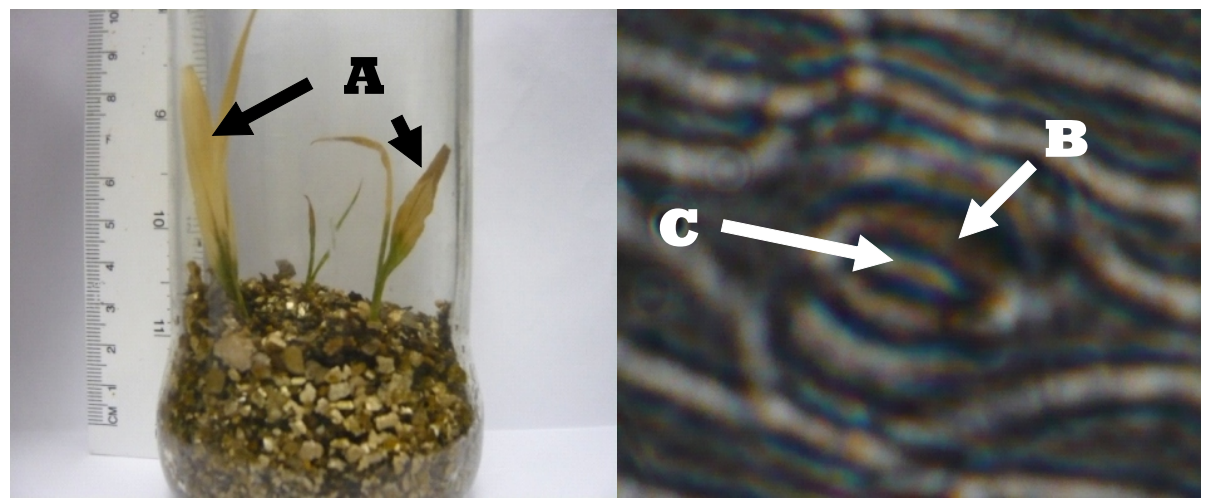

Figure 2. Severe chlorophyll degradation (A), due to high level of $\mathrm{NaCl}(684.43 \mathrm{mM})$, leading to damage or death of cells (B) thereby causing stomata to lock-open (C) in both ambient $\mathrm{CO}_{2}$ and PPFD.

Prats et al. (2006) reported that in barley, stomata locked open as a consequence of epidermal cell death especially at the proximity of the dead cells. In general, the ionic toxicity of salt stress plays a major role in membrane injury, organelle damage and pigment degradation prior to cell death. This is well documented in many plant species such as Centaurea rugusina (Radic' et al., 2005; Radic' et al., 2006), Fraxinus angustifolia 
(Tonon et al., 2004), Populus balsamifera (Chen et al., 2002), Asteriscus maritimus (Rodriguez et al., 2005), Lupinus consentinii (Legocka and Kluk, 2005), Vigna sinensis (Costa et al., 2007) and Tamarindus indica (El-Siddig etal., 2004).

\section{CONCLUSION}

Elevated carbon dioxide $\left(380 \pm 100 \mu \mathrm{mol} \mathrm{CO}_{2} / \mathrm{mol}\right)$ and PPFD $(50 \pm 5$ $\left.\mu \mathrm{mol} \mathrm{m} \mathrm{s}^{-2}\right)$ increased the net phosynthetic rate $\left(\mu \mathrm{mol} \mathrm{CO} \mathrm{Cm}^{-2} \mathrm{~s}^{-1}\right)$ of oil palms under saline condition. With increased net photosynthetic rate, plant dry weight and percent dry matter were subsequently increased. The same increase in net photosynthetic rate is essential to affect an increase in water use efficiency. These findings show the possibility of using net photosynthetic rate as a physiological criterion for salinity tolerance screening in oil palm breeding programs e.g. higher Pn translating to better performance of oil palm under saline condition.

\section{ACKNOWLEDGEMENT}

The authors would like to express their utmost gratitude to the Interventional Cooperation Division (ICD) of the National Center for Genetic Engineering and Biotechnology (BIOTEC) thru their Human Resource Development Program in Biotechnology for Asia Pacific (HRDP) and Cebu Technological University - Barili Campus for making this experiment possible.

\section{REFERENCES}

ADELBERGE J., K. FUJUWARA, C. KIRDMANEE, and T. KOZAI. 1999. Photoautotrophic shoot and root development for tripod melon. Plant Cell, Tissue and Organ Culture 57:97-104.

ASHRAF M. and M.R. FOOLAD. 2007. Role of glycine betaine and proline in improving plant abiotic stress resistance. Environmental and Experimental Botany 59:206-216.

BARISON Y. and A.N. MA. 2000. Malaysian palm oil industry: moving towards the future. Palm Oil Development 32:1-9. 
CHA-UM S., K. SUPAIBULWATANA, and C. KIRDMANEE. 2007. Glycinebetaine accumulation, physiological characterizations and growth efficiency in salt-tolerant and sal-sensitive lines of indica rice (Oryza sativa L. ssp. indica) in response to salt stress. Journal of Agronomyand Crops Science 193:157-166.

CHEN S., L. LI, T. WANG, S. WANG, A. POLLE, and A. HÜTTERMANN. 2002. Osmotic stress and ion-specific effects on xylem abscisic acid and the relevance to salinity tolerance in poplar. Journal of Plant Growth Regulation 21:224-233.

COSTA J.H., Y. JOLIVET, M.P. HASENFRATZ-SAUDER, E.G. ORELLANO, M.G.S. LIMA, P. DIZENGREMEL, and D.F. DE MELO. 2007. Alternative oxidase regulation in roots of Vigna unguiculata cultivars differing in drought/salt tolerance. Journal of Plant Physiology 164:718-727.

DE HERRALDE F., C. BIEL, R. SAVẺ, M. A. MORALES, A. TORRECILLAS, J.J. ALARC'ON, and M.J. SĀNCHEZ-BLANCO. 1998. Effect of water and salt stresses on the growth, gas exchange and water relations in Argyranthemum coronopifolium plants. Plant Science 139:9-17.

EL-SIDDIG K., S. INANAGA, A.M. ALI, J. GEBAUER, and G. EBERT. 2004. Response of Tamarindus indica $\mathrm{L}$. to iso-osmotic solutions of $\mathrm{NaCl}$ and PEG during germination.Journal of Applied Botany 78:1-4.

JALANI B.S., S.C. CHEAH, N. RAJANAIDU and A. DARUS. 1997. Improvement of palm oil through breeding and biotechnology. Journal of the American Oil Chemists'Society 74:1451-1455.

KIRDMANEE C., Y. KITAYA and T. KOZAI. 1995. Effects of $\mathrm{CO}_{2}$ enrichment and supporting material in vitro on photoautotrophic growth of Eucalyptus plantlets in vitro and ex vitro. In Vitro Cellular and Developmental Biology 31:144-149.

LEGOCKA J. and A. KLUK. 2005. Effect of salt and osmotic stress on changes in polyamine content and arginine decarboxylase activity in Lipinus luteus seedlings. Journal of Plant Physiology 162:662-668. 
LICHTENTHALER H.K. 1987. Chlorophylls and carotenoids: Pigments of photosynthetic biomembranes. Methods in Enzymology 148:350-380.

LUTTS S., M. ALMANSOURI, and J.M. KINET. 2004. Salinity and water stress have contrasting effects on relationship between growth and cell variability during and after stress exposure in durum wheat callus. PlantScience 167:9-18.

MOSALEEYANON K., S.M.A. ZOBAYED, F. AFREEN, and T. KOZAI. 2005. Relationships between net photosynthetic rate and secondary metabolite contents in St. John's wort. Plant Science 169: 523-531.

NETO N.B., S.M. SATURNINO, D.C. BOMFIM, and C.C. CASTŎDIO. 2004. Water stress induced by manitol and sodium chloride in soybean cultivars. Brazilian Archives of Biology and Technology 47:521-529.

NGUYEN Q.T., T. KOZAI, and U.V. NGUYEN. 2000. Effects of sucrose concentration, supporting materials and number of air exchanges on the vessel on the growth of in vitro coffee plantlets. Plant Cell, Tissue and Organ Culture 58:51-57.

OIL WORLD. 2004. Oil World Annual. ISTA Mielke, Hamburg.

PARIDA A.K., and A.B. DAS. 2005. Salt tolerance and salinity effects on plants: a review. Ecotoxicology and Environmental Safety 60:324-349.

PRATS E., A.P. GAY, L.A. MURR, B.J. THOMAS, and T.L.W. CARVER. 2006. Stomatal lock-open, a consequence of epidermal cell death, follows transient suppression of stomatal opening in barley attacked by Blumeria graminis. Journal of Experimental Botany 57(10):2211-2226.

RADIĆ S., M. PROLIĆ, and B. PEVALEK-KOZLINA. 2005. Cytogenetic effects of osmotic stress on the root meristem cells of Centaurea ragisina $\mathrm{L}$. Environmental and Experimental Botany 54:213-218. 
RADIĆ S., M. RADIĆ-STOJKOVIĆ, and B. PEVALEK-KOZLINA. 2006. Influence of $\mathrm{NaCl}$ and mannitol on peroxidise activity and lipid peroidation in Centaurea ragisina L. roots and shoots. Journal of Plant Physiology 163:1284-1292.

RAJANAIDU N., and B.S. JALANI. 1994. Prospects for breeding for kernels in oil palm (Elaeis guineensis). Planter 70:309-318.

RODRIGUEZ P., A. TORRECILLAS, M.A. MORALES, M.F., ORTUNO, and M.J., SANCHEZ-BLANCO. 2005. Effects of $\mathrm{NaCl}$ salinity and water stress on growth and leaf water relations of Asteriscus maritimus plants. Environmental and Experimental Botany 53:113-123.

SHABALA S.N., S.I. SHABALA, A.I. MARTYNENKO, O. BABOURINA, and I.A. NEWMAN. 1998. Salinity effects on bioelectric activity, growth, $\mathrm{Na}^{+}$ accumulation and chlorophyll fluorescence of maize leaves: a comparative survey and prospects for screening. Australian Journal of Plant Physiology 25:609-616.

TONON G., C. KEVERS, O. FAIVRE-RAMPANT, M. GRAZIANI, and T. GASPAR. 2004. Effects of $\mathrm{NaCl}$ and mannitol iso-osmotic stresses on proline and free polyamine levels in embryogenic Fraxinus angustifolia callus. Journal of Plant Physiology 161:701-708. 